\title{
Transurethral Microwave Thermotherapy of the Prostate
}

National Cancer Institute

\section{Source}

National Cancer Institute. Transurethral Microwave Thermotherapy of the Prostate. NCI Thesaurus. Code C89823.

A procedure for treatment of benign prostatic hypertrophy that uses microwave energy delivered through the urethra to destroy prostate tissue. 